2003

\title{
Legal Services in the Doha Round
}

Sydney M. Cone III.

New York Law School, sydney.cone@nyls.edu

Follow this and additional works at: https://digitalcommons.nyls.edu/fac_articles_chapters

Part of the Law and Economics Commons

\section{Recommended Citation}

37 Journal of World Trade 29-47 (2003)

This Article is brought to you for free and open access by the Faculty Scholarship at DigitalCommons@NYLS. It has been accepted for inclusion in Articles \& Chapters by an authorized administrator of DigitalCommons@NYLS. 


\title{
Legal Services in the Doha Round
}

\author{
Sydney M. CONE III*
}

\section{INTRODUCTION}

As a subcategory of professional services and a sub-subcategory of business services, legal services, when supplied transnationally, are the subject of negotiation in the current round of multilateral trade negotiations known as the Doha Round. Although this is the first round to be held under the aegis of the World Trade Organization (WTO), as distinguished from its predecessor, the General Agreement on Tariffs and Trade (GATT), it is the second round of multilateral trade negotiations to involve services generally and legal services in particular. The Uruguay Round (1987-1993), under the aegis of the GATT, created not only the WTO but also the General Agreement on Trade in Services (GATS). ${ }^{1}$ Both the WTO and the GATS came into effect on 1 January 1.995, and the latter, upon coming into effect, contained specific commitments and other provisions relating to legal services-as well as other categories of services-that had been negotiated and agreed to during the Uruguay Round by countries that became WTO Members.

Because, in terms of economic magnitude and political heft, legal services, relatively, have not figured prominently under the GATS, they are not expected to be a major factor in the Doha Round. Moreover, that round is not expected to be concluded for some time, and past experience suggests that legal services will figure only in an ancillary fashion in the overall process of negotiation-of tough bargaining over a complex and wide variety of goods, services, intellectual

* C.V. Starr Professor of Law, New York Law School; Senior Counsel, Cleary, Gottlieb, Steen \& Hamilton.

1 The Doha Round was undertaken by WTO Members pursuant to a Ministerial Declaration adopted on 14 November 2001 at a Ministerial Conference in Doha, Qatar, WT/MIN(01)/DEC/1 (20 November 2001). The GATS is Annex 1B to the Agreement Establishing the World Trade Organization as signed on 15 April 1994 in Marrakesh, Morocco. Specific commitments and exemptions from most-favoured-nation treatment relating to legal services are set out under (1) Horizontal Commitments and (2) Sector-Specific Commitments annexed as schedules to the GATS for the respective WTO Members. The Sector-Specific Commitments for Legal Services are found under "Professional Services", which in turn are found under "Business Services", in the relevant schedules. Uruguay Round of Multilateral Trade Negotiations, Annex 1b, vols 28-30 (Geneva: GATT Secretariat, 1994). The classification of services is found in WTO Services Sectoral Classification List, Doc. MTN.GNS/W/120. 
property, and trade policies. ${ }^{2}$ Even so, the negotiations on legal services that take place in the Doha Round have considerable potential for affecting the economics and activities of lawyers and law firms, and for influencing the content of local professional rules governing the practice of law. This article will examine that potential.

A key word in the preceding paragraph is "local". Legal services are rendered by practitioners acting as individual lawyers or, more frequently in the context relevant to this article, as members or employees of law firms. These practitioners are licensed by local authorities under local rules that have their genesis in local tradition and experience. Although concepts relating to international trade in legal services can be abstracted into terminology and categories compatible with the GATS-compatible, that is, with concepts derived from the jurisprudence of multilateral trade-the regulation of the legal professions of the world is, in reality, intensely parochial. It is this parochialism that gives legal services a certain singularity in the Doha Round, and that must be understood at the outset before one can evaluate the potential of the Doha Round in respect of legal services.

Indeed, as one considers the implications of parochialism for multilateral trade negotiations concerning legal services, one at some point will almost inevitably ask oneself, is it useful to include legal services in the Doha Round? After all, a round of WTO-sponsored negotiations is aimed not so much at the particularized governance of diverse legal professions as at commercial products which, whatever their source, are by their very nature rather fungible and free from heterodoxy. Thus, a companion question arises: Are there not, for legal services, useful alternatives to an undertaking such as the Doha Round? This article will examine both sides of these questions, and will suggest that (notwithstanding the force of certain arguments to the contrary) the Uruguay Round, for better or for worse, may already have prejudged the answer. That is, legal services having already been included in that round as a (sub-sub-) category under the GATS, to decide now to exclude legal services from the Doha negotiations could, at a minimum, create an appearance of retrogression and protectionism unhelpful to the cross-border practice of lawunhelpful, that is, to lawyers and law firms engaged in that practice and, perhaps of even greater relevance, to their clients.

\footnotetext{
2 According to the WTO, in 2000 the value of world exports of all commercial services was US $\$ 1,435$ billion, and the value of world exports of all merchandise was US $\$ 6,186$ billion. The WTO broke down these totals into major categories, but legal services do not constitute one of those major categories: <www.wto.org/ english/[-]res_e/statis_e/its2001_e/chp_4_e.pdf?. National data for legal services present a special problem because the data (a) do not distinguish between legal services (i) performed in a home country for the benefit of clients in other countries and (ii) performed in host-country establishments, and (b) probably also do not distinguish between fees and reimbursed expenses. See Sydney M. Cone, III, International Trade in Legal Services (Boston: Little Brown, 1996), at 1:19 (analysis of legal-service data released by the US Department of Commerce) (hereinafter "Cone 1996"). As discussed in this article, legal services performed in host-country establishments constitute the principal category of legal services at issue in the Doha Round. On the ancillary nature of legal services in the Uruguay Round, see Cone, as above, at 2:12-13, 2:42-44 (apparent trade-off involving US legal services and Japanese semiconductors).
} 
This article reaches this answer after examining a somewhat complicated landscape.

- First, it asks which WTO Members are the major suppliers and users of legal services; in this connection, it will focus on the European Union and the United States, and their respective bilateral and multilateral interests.

- Next, it considers arguments involving the globalization of legal practice, and the interests of countries viewed, on the one hand, as the beneficiaries of, and, on the other hand, as the targets of, globalization.

- Third, it sets out and analyses the proposition that the Doha Round negotiations should abstract legal services into categories of professional arrangements, and should then attempt to foster agreements framed in terms of formal categories deemed susceptible of incorporation into schedules of GATS commitments.

- Fourth, it examines the possibility, under the GATS, of taking a lesser or parallel step known as developing multilateral professional disciplines, rather than seeking to negotiate full-blown agreements based on national schedules of specific commitments.

- Finally, on the basis of the review and analysis thus conducted, the article attempts to reach a balanced conclusion to the question: Is it helpful to include legal services in the Doha Round?

\section{Major Cross-border SUPpliers and USERS OF LEgAl SER Vices}

Legal services are included under the GATS (which, as its name indicates, is an agreement on trade in services) as though they were an item of trade being imported into and exported from WTO Member countries. ${ }^{3}$ In the case of legal services, this concept is a sometimes confusing fiction, and in practice the fiction is often ignored. Instead, the practice that evolved in the Uruguay Round was for the essential negotiations on legal services to focus on rights of establishment (and rights ancillary thereto) that law firms seek and, where available, assert and implement outside their home countries. For this purpose, the relevant WTO Member countries are home members and host members. A law firm's home member is the country in which the firm is present, conducts a substantial and regular legal practice, and is treated by the firm itself as its home country. A host member in respect of that firm is any WTO Member country, other than the firm's home member, in which the firm establishes or seeks to establish itself for the purpose of supplying legal services. Accordingly, in the area of legal services, the Uruguay Round focused on the rights of home-member law firms to create establishments in host members, and to staff those establishments with lawyers from, among other places, the relevant home member.

${ }^{3}$ See, generally, Laurel Terry, GATS'Applicability to Transnational Lawyers and its Potential Impact on Domestic Regulation of U.S. Lawyers, 34 Vanderbilt J. Transnational L. (2001), 989; see Cone, as note 2 above, at 5-6. 
The European Union and the United States are the leading WTO Members in terms both of supplying legal services through establishments in host members, and using legal services supplied by establishments of law firms from other home members. ${ }^{4}$ That is, EU and US law firms are leaders in establishing themselves outside their home countries, and the European Union and the United States are leading centres of legal practice that include establishments of non-home-member law firms. In this sense (employing the fiction that legal services are imported and exported), it can be said that the European Union and the United States are leaders as both importers and exporters of legal services.

Cross-border legal practice is hardly confined to EU and US law firms. There are host-country establishments in many other WTO Members, of which China, Japan, Hong Kong and Singapore are notable examples. Moreover, countries such as Australia, Brazil and Canada are WTO home members that both permit the establishment of law firms from other home members, and have their own homemember law firms whose operations include establishments in other host members. ${ }^{5}$

As has been mentioned, the European Union and the United States are not only the leading host members, but also the leading home members; thus, they have legalservice establishments in other host members, including, importantly, each other. One not surprising consequence of this comparability of the European Union and the United States is the existence of concessions that they would like to obtain from each other in the area of legal services. Given their predominance in this area, it might be thought that, as between themselves, the European Union and the United States would simply enter into bilateral negotiations with a view to agreeing on mutual concessions. Here, however, two critical factors must be taken into account, one involving domestic regulation of legal practice, the other involving the GATS, each fundamentally affecting legal services in the Doha Round.

1. The regulation of the legal profession, including the regulation of foreign lawyers, is uniform neither within the European Union nor within the United States. This lack of uniformity has major implications for transnational rules on legal services.

2. An essential rule under the GATS is the requirement of most-favourednation (MFN) treatment. In the absence of an expressly agreed exemption from MFN treatment, a WTO Member must accord all other WTO Members treatment no less favourable than that accorded the WTO Member receiving most-favoured treatment from the WTO Member in question.

\footnotetext{
4 See WTO Council for Trade in Services, Background Note, S/C/W/43, at 8 (no. 28).

5 See the entries for these countries in Martindale-Hubbell International Law Directory (New Providence: Martindale-Hubbell/Lexis, 2002).
} 


\section{A. THE EUROPEAN UNION}

Variations in the legal systems of the 15 countries that are members of the European Union have been the subject of detailed commentary. ${ }^{6}$ These variations account for the protracted negotiations that were necessary until, in 1998, the European Union adopted an Establishment Directive in respect of legal services. ${ }^{7}$ The $15 \mathrm{EU}$ member countries are required to implement the Directive by appropriate national measures. ${ }^{8}$ To the extent that the Directive has been implemented, it creates a system under which a duly licensed legal practitioner from any EU home country is entitled to establish himself or herself in every other EU country. Under the Directive, the practitioner thus established in an EU host country is authorized, using his or her home-country professional title, to provide legal services relating to home-country, host-country and third-country law. Additionally, such a practitioner, after having been established in an EU host country for a certain period of time, is entitled to qualify, at his or her option, as a member of a legal profession in the host country. An analogous, although somewhat more qualified, right of establishment is also conferred by the Directive on law firms (as distinguished from individual lawyers). Here, in many cases, the Directive enables a law firm from an EU home member-country to establish itself in EU host member countries. The potential qualifications of this right of establishment relate to (a) possible general restrictions in the host country with regard to legal practice by law firms, and (b) possible restrictions where the law firm is not entirely controlled by nationals of the 15 EU member countries. 9

The European Union's Establishment Directive expressly confines the individual rights thereunder to nationals of the $15 \mathrm{EU}$ countries. ${ }^{10}$ Thus, a legal practitioner from a non-EU country, even if he or she qualifies as a member of a legal profession in an EU country, is not entitled to the benefits of the Directive. It seems most unlikely that this aspect of the Directive will be changed. In theory, the United States might attempt to reach a bilateral agreement with the European Union whereby every US national who qualified as a legal practitioner in an EU country would be entitled to the benefits of the Directive. Such a bilateral agreement, it might be argued, would be far more beneficial to the US legal profession than potential benefits to be attained pursuant to the Doha Round.

There are, however, rather serious impediments to achieving such a bilateral result. First, the EU member countries encountered considerable difficulty over a long

${ }^{6}$ E.g., Cone, as note 2 above, chs $7-11$.

7 Directive 98/5/EC of the European Parliament and of the Council, 15 February 1998, to facilitate practice of the profession of lawyer on a permanent basis in a Member State other than that in which qualification was obtained, OJ L077 (14 March 1988), at 0036-0047 (hereinafter "EU Directive").

8 France, Ireland, Luxembourg and the Netherlands have yet to adopt national legislation implementing the EU Directive; the 11 other EU Member States have adopted such legislation.

9 The respective provisions of the EU Directive referred to in this paragraph are Articles 2, 5.1, 10.3, and 11 .

10 This results from the definition of lawyer in Article 1.2(a) of the EU Directive as one who is "a national of a Member State". 
period in negotiating the Establishment Directive just among themselves, ${ }^{11}$ and they might lack the political will to embark on the further intra-EU negotiations that would be required in order to extend the Directive to non-EU nationals. Second, as discussed below, it would probably prove difficult for the United States to put itself in a position where it could offer to the European Union advantages for EU legal practitioners established in the United States of a type that the European Union would deem a suitable counterpart for granting rights under the Directive to US practitioners established in the European Union. Finally, as mentioned above, there is the matter of MFN treatment, meaning that the European Union and the United States could not simply enter into a bilateral agreement without either extending its benefits to all WTO Members, or else granting trade concessions that would permit them successfully to claim an MFN waiver for legal services in the Doha Round negotiations.

Another bilateral objective that the United States might seek from the European Union outside the Doha Round is the repeal of the EU's doctrine under a decision by the European Court of Justice, known as the AMES case, whereby client communications to lawyers in the European Union may not benefit from attorneyclient privilege if the lawyers are not qualified EU legal practitioners. ${ }^{12}$ This distinction between EU and non-EU legal practitioners established in the European Union, which accords attorney-client privilege in the case of the former but not the latter, and thus gives a competitive advantage to the former as compared with the latter, has much vexed US law firms established in EU host countries. ${ }^{13}$ The abolition of this distinction could conceivably be the subject of a bilateral arrangement between the United States and the European Union. Even so, this limited objective, it might be argued, could equally well be dealt with in a multilateral agreement on attorney-client privilege entered into in the context of the Doha Round.

As a practical matter, however, it might prove impractical to focus the many participants in the Doha Round in an effective manner on the discriminatory implications of the $A M E S$ case, whereas US bar associations are quite focused on this issue and are probably well positioned to lobby for it to be dealt with in bilateral EUUS negotiations. If the United States were successful in such negotiations, the result might be unilateral action by the European Union applied generally for the benefit of

11 See Roger Goebel, Lawyers in the European Community: Progress Towards Community-Wide Rights of Practice, 15 Fordham Int'l L. J. (1991-92), 556; Heinz Weil, The Proposal for a Directive on the Right of Establishment for Lawyers in the European Community, id., at 699; see Cone, as note 2 above, at 8:12-8:26.

${ }_{12}$. AMES Europe Limited v. Commission, Case 155/79 (18 May 1982), Common Market Reports \$8757. In that case the staff of the European Commission, in the course of investigating alleged antitrust violations, had requested documents that $A M \& S$ Europe Limited had refused to provide on the ground of attorney-client privilege involving in-house counsel. The Commission rejected the claim of privilege, and the issue was brought before the European Court of Justice which, in dictum, observed that "written communications between lawyer and client must apply without distinction to any lawyer entitled to the practice of his profession in one of the Member States, regardless of the Member State in which the client lives". This dictum has been cited as authority for the proposition that, in the EU, communications by clients to non-EU lawyers are not privileged.

13 The ABA House of Delegates, in February 1983, resolved that a client should enjoy the same privilege in respect of communications with a US lawyer that the client enjoys in communications with an EU lawyer. 
non-EU legal practitioners established in the European Union. Thus, while the $A M E S$ issue is one that the United States has been pressing and is likely to continue to press to have resolved, its resolution in a manner favourable to non-EU legal practitioners would seem to depend on unilateral decisions taken within the European Union itself.

Finally, judging from unofficial indications of what the European Union will be seeking in the Doha Round with respect to legal services, its focus may be less on improving access in the United States for EU law firms than on raising the level of multilateral commitments in order to gain access for EU law firms in countries with restrictive policies on the right of establishment. Korea and other Asian countries, for example, and possibly certain Latin American countries, may fall in this category. ${ }^{14}$ As for the United States, quite a few EU law firms are well established there, especially in New York, and some of these establishments are substantial in size and effectively operate as though they were domestic US firms. ${ }^{15}$ While there are ways in which the United States might further benefit EU firms, improvements of this sort may seem rather marginal when compared to the lifting of barriers in restrictive jurisdictions through multilateral negotiations.

\section{B. THE United StATES}

The practice of law is regulated by the several states of the United States. Great disparity exists among the states as regards the treatment of non-US legal practitioners established, or seeking to become established, in a particular US state. In the (theoretical) event of bilateral EU-US negotiations on legal services, the United States will perforce need to take these disparities into account and thus might not find it easy to speak in a meaningful way with a single voice on behalf of all of the US states including those where protectionist rules apply to the practice of law.

The United States is represented in the Doha Round by the United States Trade Representative (USTR), which in turn, as regards legal services, looks for guidance to the American Bar Association (ABA) - a large, voluntary association of lawyers. In anticipation of the Doha Round, the ABA adopted a resolution endorsing its 1993

14 See documents made available 17 April 2002 at <http://www.guardian.co.uk/Print/ 0,3858,4395515,00.html> (providing 29 non-public European Commission documents, designated MD: 040/02 through MD: 068/02 (6 March 2002), setting out GATS requests from the EU and its Member States to, respectively, India, Canada, the United States, Australia, New Zealand, the Philippines, Switzerland, Colombia,
Panama, Malaysia, Pakistan, Singapore, China, Taiwan, Hong Kong, Japan, Korea, Indonesia, Thailand, Argentina, Brazil, Chile, Paraguay, Uruguay, Venezuela, Egypt, Israel, South Africa, Mexico). With regard to the United States, there have been suggestions that all US jurisdictions should adopt the ABA's Model Rule for the Licensing of Legal Consultants (August 1993). See, e.g., Jonathan Goldsmith, U.S. doors remain closed to foreign lawyers, European Lawyer (June 2002), 24. Given the substantial presence and scope of practice of foreign law firms in the United States, examples of which are referred to in the following footnote, these suggestions may be susceptible of interpretation as defensive EU posturing for purposes of the Doha Round.

15 See, e.g., the listings for Allen \& Overy, Clifford Chance, Freshfields Bruckhaus Deringer, Linklaters, Lovells in 12 Martindale-Hubbell Law Directory (New Providence: Martindale-Hubbell/Lexis, 2002) at, respectively, NYC75B-78B, NYC262B-283B, NYC503B-504B, NYC877B-878B, NYC888B-889B. 
Model Rule on Foreign Legal Consultants. ${ }^{16}$ The substantive relevance of this endorsement in the context of the Doha Round not being immediately apparent, an effort at explaining its relevance is set out in the immediately following paragraphs.

The ABA Model Rule is a virtual copy of legal-consultant rules which were originally adopted in the State of New York. (The 1993 ABA Model Rule tracks the New York legal-consultant rules as adopted in 1974 and subsequently amended.) Looked at on the basis of New York's legal-consultant rules, the ABA Model Rule can be interpreted in light of almost 30 years of experience and jurisprudence developed in New York. Viewed in isolation outside New York, however, the ABA Model Rule is far less meaningful. Most of the states of the United States do not have any legalconsultant rules, and most of the US states that have adopted legal-consultant rules have not adopted key provisions of the ABA Model Rule. In other words, when the ABA Model Rule is compared with the rules of all of the states of the United States, it takes on the character not of a model that has been widely followed but of one that is largely precatory.

The "legal consultant" concept was adopted by New York to facilitate granting foreign law firms a right of establishment in New York. Thus, lawyers in a foreign law firm could be licensed as "legal consultants" without examination (that is, without having to qualify as members of the New York Bar) to practice law in New York, and this right, combined with (a) the right to associate (as partners or otherwise) with New York lawyers, and (b) the right to advise on home-country, host-country and thirdcountry law, constituted a meaningful right of establishment for foreign law firms located in New York. ${ }^{17}$ This right is not found in most US states, however, where the legal-consultant rules, if any, have not followed the New York/ABA Model Rule pattern of permitting licensed legal consultants to advise on host-country law and to create host-country legal practices. Thus, were bilateral EU-US negotiations to occur, the European Union might well question whether the United States was in a position

16 Resolution of the ABA House of Delegates, February 2002, stating that the ABA "supports negotiation proposals to the United States Trade Representative regarding access to foreign markets for US lawyers through permanent establishments consistent with, and as expressed and incorporated in, the ABA's 'Model Rule for the Licensing of Legal Consultants' in the United States". (The ABA's Model Rule was adopted by the ABA House of Delegates in August 1993 and has not been modified. Although 24 US jurisdictions have legal-consultant rules, most of them differ materially from the ABA's Model Rule. See Cone, as note 2 above, ch. 4.) See also ABA Section of International Law and Practice, Report 113E to the House of Delegates (3 February 2002). Although, at the time this article went to press, the United States had not announced its position on legal services in the Doha Round, it is expected that that position will be based on (1) the ABA's Model Rule, and (2) the common position of New York bar associations referred to in the next footnote.

17 Rules of the New York Court of Appeals, Part 521. On the basis of these rules and over 28 years of experience thereunder, the New York State Bar Association and the Association of the Bar of the City of New York, in April 2002, adopted a common position on the Doha Round negotiations on legal services. Briefly, this common position called for a multilateral right of establishment in host countries for lawyers and law firms from home countries, entitling the establishment (1) to comprise home-country, host-country and third-country lawyers, and (2) to supply legal services (a) which the lawyer or law firm was entitled to supply in the home country, and (b) relating to the law of the host country if, where appropriate, the services were based on the services of host-country lawyers who could be lawyers within the establishment itself. This common position was endorsed by the Legal Services Committee of a US trade group, the Coalition of Service Industries. For this common position, see Sydney M. Cone III, New York and Legal Services in Negotiations Under the General Agreement on Trade in Services (Geneva, 19 July 2002; on file with the WTO Secretariat). 
to grant EU law firms a meaningful right of establishment throughout the United States. More precisely, the European Union might question the breadth of the mandate enjoyed by the USTR in the area of legal services.

Three other aspects of the US position in such hypothetical bilateral negotiations should be mentioned:

1. Even in New York and in the ABA Model Rule, there are limitations on the rights of legal consultants that, in the age of the Doha Round, may seem antiquated. Legal consultants in New York are subject not only to restrictions involving appearances in that state's courts, which must be the active responsibility of members of the New York bar or of lawyers specially admitted by the court, but also to restrictions involving (1) transfers of title to real property in New York, (2) family law matters relating to US citizens, and (3) the preparation of documents in New York governing inheritance under New York law by US citizens. ${ }^{18}$ These last three restrictions were deemed politically necessary some 30 years ago in order to deal with protectionist opposition to the adoption of New York's legal-consultant rules. Other US states have copied these restrictions and, in a number of cases, have added to them. Perhaps the New York restrictions are so entrenched and are so limited in nature that they have become immutable. Their retention, however, might provide the European Union with negotiating points in the event bilateral EU-US negotiations on legal services were to occur.

2. In 2001, New York adopted rules on multidisciplinary practice (MDP) that limit MDP in New York to contractual arrangements between lawyers and certain non-legal professionals, and that forbid the latter to have an ownership or investment interest in, or otherwise to control, a legal practice in New York. ${ }^{19}$ In certain EU countries, however, MDP is not subject to these strictures. It is conceivable, therefore, that issues relating to MDP could complicate bilateral negotiations between the European Union and the United States on legal services, although it seems more likely that rules on MDP would be excluded from such negotiations and left to the discretion of local regulatory authorities.

3. The states of the United States are just beginning to develop rules on multijurisdictional practice (MJP) among the several US states. In August 2002, the ABA adopted a resolution on MJP which, so far as non-US law

${ }^{18}$ Id., $₫ 521.3$.

19 New York Lawyer's Code of Professional Responsibility, Disciplinary Rules 1-106, 1-107. For the relevant background report, see New York State Bar Association Committee on the Law Governing Firm Structure and Operation, Report on Preserving the Core Values of the American Legal Profession: The Place of Multidisciplinary Practice in the Law Governing Lawyers (April 2000). For subsequent US Federal law, see the Sarbanes-Oxley Act of 2002, $\ 201$ (a), adding, inter alia, new $\(\mathrm{~g})(8)$ to Section $10 \mathrm{~A}$ of the Securities Exchange Act of 1934. In the European Union, the European Court of Justice has held that rules adopted in the Netherlands on MDP, rules which are not dissimilar from the New York Rules on MDP, are not incompatible with the Treaty of Rome. J.C.J. Wouters, J.W. Savelbergh, Price Waterhouse Belastingadviseurs BV v. Algemene Raad van de Nederlandse Orde van Advocaten, ECJ C-309/99 (19 February 2002). 
firms are concerned, does little except, once again, commend the 1993 ABA Model Rule on Legal Consultants to the attention of the several US states and, in addition, suggest that they look favourably on temporary "fly-in, flyout" visits by foreign lawyers. By itself, the ABA resolution on MJP does little to promote the right of establishment of foreign law firms in the United States, and this factor might not escape the attention of EU negotiators in the event of bilateral EU-US negotiations on legal services. ${ }^{20}$

In sum, bilateral EU-US negotiations on legal services would appear to be a problematic substitute for the multilateral Doha Round. Even so, many of the considerations set forth above relating to hypothetical bilateral EU-US negotiations are hardly irrelevant in the multilateral context and may manifest themselves, directly or indirectly, in the course of the Doha Round. Because law firms from the European Union and the United States are predominant in seeking rights of establishment and because international legal centres in those two countries tend to set the pace as regards granting rights of establishment to law firms from other home countries, EU-US interaction on legal services, even if they do not ripen into formal bilateral negotiations as such, may prove to have a significant influence on how the Doha negotiations in fact proceed.

\section{Legal Services and Attitudes Toward Globalization}

The predominance of the European Union and the United States in the area of legal services rather predictably gives rise to arguments that have become familiar in a more general setting with respect to globalization and the WTO. Detractors of the WTO often claim that it is a creature of multinational enterprises reaping the benefits of globalization primarily for industrialized nations. ${ }^{21}$ With regard to the GATS, its critics have suggested that its principal beneficiaries are major providers of services based in industrialized countries, seeking access to markets in developing countries in order to keep the latter in a state of economic subordination. ${ }^{22}$ The undeniable fact that law firms with global ambitions and capabilities are to a great extent based in industrialized nations makes it superficially tempting to include legal services among the services claimed to be part of an effort to exploit the GATS for the benefit of more industrialized countries seeking expansion if not domination in countries that are less industrialized.

It should be recognized, however, that the role of law firms, even of global law firms, as facilitators of globalization, is rather different from the role of the clients of

20 The substance of the ABA position on MJP is found in Report of the Commission on Multijurisdictional Practice (ABA, August 2002).

${ }_{21}$ See, e.g., articles posted on <http://www.prospect.org/issue_pages/globalization/> esp. Joseph E. Stiglitz, Globalism's Discontents. See also Center for Research on Globalization: <http://www.globalresearch.ca/> .

${ }^{22}$ See, e.g., Jeff Faux, A Deal Built on Sand, The WTO's Recent Doha Meeting is a Fast Track to Chaos: <http:/ /www.prospect.org/print/V13/1/faux-j.html>. 
law firms. It is the clients that constitute the business, commercial and financial engines of globalization. Their economic muscle is the driving force that has wrought a globalized economy. To the extent that they need lawyers to facilitate their activities they will find them, whether in home countries or host countries or third countries, whether by retaining firms of lawyers or by hiring individual practitioners or by creating corporate in-house teams of lawyers. True, once a governmental authority or a non-governmental organization or a private enterprise concludes that the net effect of globalization is harmful or pernicious, it (the opponent of globalization) will probably be inclined to reason that there is no compelling reason to distinguish between clients and their lawyers. This may seem a mighty fine distinction in the mind of a person for whom globalization poses a threat that must be tempered or avoided.

Failure to make this distinction may serve, however, to mask the essentially protectionist agenda of a number of opponents of rights of establishment for law firms from other countries. The primary effect of denying this right to foreign law firms is not to stem the progress of globalization-it indeed may have scant effect on the forces of globalization-but to shelter domestic legal practitioners from competition. The practice of law is highly competitive, particularly where the clients are engaged in global business, commerce or finance. Here, the typical lawyer-client relationship is one in which the lawyer is the supplicant, the anxious caretaker of the relationship, and in which the client is quite free to choose among potential suppliers of legal services. Clients, moreover, stand to benefit when they are able to choose among a broad spectrum of potential suppliers, domestic and foreign. It is the local bar, not the local client, that is likely to sound the alarm that foreign lawyers are coming, to decry the consequences of globalization for national culture, and to insist that the intruders be repulsed or, at least, tightly controlled.

This protectionist phenomenon in the area of legal practice is not uniquely a function of attitudes toward globalization, and protectionism in the legal profession is not confined to jurisdictions in the less-industrialized world. ${ }^{23}$ Certain member countries of the European Union and certain states of the United States have rules that effectively restrain competition by establishments of foreign lawyers. This type of parochialism antedated the era of globalization, and is a useful indicator of the nature of some of the forces at work when a local bar raises the threat of globalization as a reason for erecting barriers against the creation of meaningful rights of establishment for law firms from other countries.

It should also be recognized that the exclusion of foreign law firms from a particular jurisdiction may be self-defeating. The professional skills that clients seek in major cross-border transactions may tend to gravitate toward centres of international practice in other jurisdictions, and legal work relating to the protectionist jurisdiction may in fact be done in such a centre in another jurisdiction. This result could handicap the development of the legal profession in the protectionist jurisdiction, and effectively

${ }^{23}$ See Cone, as note 2 above, at 1:16-17, 1:20. 
cause an outflow of legal work to localities that afford a right of establishment to foreign firms and that thereby receive the professional stimulus of competition among a variety of firms.

In addition, it should be recognized that domestic professional organizations may lack the political power to maintain protectionist policies over a long period. Clients seeking the benefits of a multiplicity of providers of legal services may become impatient with local bar groups attempting to curtail competition, and governments may find that, in the interests of clients and in the context of multilateral trade negotiations, it is desirable or at least expedient to provide greater cross-border access to establishments of law firms from other countries.

All of this said, it cannot be denied that an observer who begins the Doha Round with an anti-globalization perspective is likely to include legal services in the category of services that should be denied new opportunities for expansion. Such an observer will almost certainly notice that the strongest promoters of new opportunities for the expansion of legal services in the Doha Round are law firms whose home countries are among the world's more industrialized nations. It would therefore seem predictable that anti-globalization forces will react by resisting the creation of robust rights of establishment for these firms.

\section{The Proposed Abstraction of Legal Services in the Doha Round into} FORMAL CATEGORIES

The suggestion has been made by Australia ${ }^{24}$ and by the International Bar Association $^{25}$ that legal services in the Doha Round might be usefully analysed by abstracting them into formal categories of legal practice and the regulation of legal practice. This intellectual exercise, it is said, will enable WTO Members, in dealing with legal services under the GATS, to categorize different types of legal services and regulatory systems and, having done so, to ascertain rather readily the areas in which they may be prepared to make specific commitments. For example, it might be argued that, if a WTO Member were willing to license foreign lawyers as legal consultants authorized to advise on home-country (but not host-country) law, that a Member, through a process of abstraction, would readily find the vocabulary that is appropriate for a specific commitment to that formal category of legal services.

Well intentioned though this approach might be, its practical effect might not prove very helpful if the objective of the Doha Round in respect of legal services is to move WTO Members toward less restrictive regimes through the creation and recognition of meaningful cross-border rights of establishment for lawyers and law

24 WTO, Council for Trade in Services Special Session, Communication from Australia-Negotiating Proposal for Legal Services, Doc S/CSS/W/67 (28 March 2001), supplemented and revised by Suppl. 1/Rev. 1 (10 July 2001).

25 International Bar Association, Legal Services Under GATS, Briefing Paper for the WTO (Geneva, 19 July 2002). See also Russell Miller and Scott Gallacher, The GATS Framework and Trade in Professional (Legal) Services, paper presented at 24th International Trade Law Conference, Canberra, Australia, 9 October 2002. 
firms. Indeed, the practical effect could easily be regressive where the terminology of decontextualization was employed to camouflage protectionist measures. An all-toopossible result is that host-country protectionist interests will be assisted in refining their opposition to meaningful cross-border rights of establishment for law firms from other countries, and that the fruits of decontextualization will be a menu of opportunism from which protectionist interests in various countries will pick and choose those aspects of legal practice concerning which they are, and, more to the point, are not, prepared to facilitate rights of establishment. As regards the example mentioned above, a WTO Member that decides to license legal consultants and to authorize them to advise on home-country (but not host-country) law does not need an abstract developed elsewhere in order to do so. In taking such a step, the member needs only its own parochial policy reasons for doing so, and its own regulatory and jurisprudential setting for finding the means of doing so effectively. ${ }^{26}$

Decontextualization is of questionable utility by virtue of two fundamental characteristics of legal-service negotiations:

- the essential issues are few in number and simple in concept, and are not clarified by formalistic abstraction;

- when these issues are dealt with in real terms, they are dealt with locally on the basis of local arrangements locally arrived at.

The second of these characteristics rather basically informs the first. Local issues are rarely expressed in abstracted GATS-speak. Being, at bottom, issues arising under local rules whose language is that of the relevant locality and whose meaning is to be found in large part in local history and jurisprudence, they require an exercise altogether different from that of formalistic reference to abstract categories. Rather than create the artifice of a universal menu of regulatory terminology, the legal-service negotiators would be well advised to undertake the painstaking task of looking at the regulation of legal services one jurisdiction at a time, in the actual, individual, historical and jurisprudential framework of each jurisdiction. Only in this manner can the negotiators obtain an understanding of how the regulation of legal services actually operates.

There are certainly issues that can be identified as commonly arising in host jurisdictions; but (as mentioned above) they tend to be few in number and simple in concept. They relate to rights of establishment for foreign lawyers and law firms in the relevant host country, and, in this context, usually can be reduced to the right of an establishment to provide legal services involving the law of the host country. Once this

26 The Australian effort at decontextualization (see note 24 above) is generally favourable to liberalizing trade in legal services, but it nonetheless would (i) prevent the Australian establishments of non-Australian law firms from advising on Australian law on the basis of advice given by Australian lawyers within those establishments, and (ii) require such establishments to refer to Australian law firms all matters involving Australian law. See $₫ 13$ of Suppl. 1/Rev. 1, cited in note 24 above (advice given by a foreign practitioner on Australian law must be expressly based on advice by an Australian practitioner not employed by the foreign practitioner). No such restriction is found in the ABA Model Rule for the Licensing of Legal Consultants, see $\$ 4(\mathrm{e})$ thereof, or Part 521 of the New York Rules, see $\$ 521.3(\mathrm{e})$ thereof, referred to in notes 16 and 17 above. 
simple issue has been recognized and used as the touchstone for a given jurisdiction, decontextualized abstraction can be dispensed with, and negotiations can proceed efficiently.

This issue often subsumes an establishment's permitted scope of practice, and the right of association enjoyed by, or denied, the legal professionals within the establishment. Scope of practice invariably comes down to rules that permit or forbid non-host-country lawyers to provide legal services involving the law of the host country. Right of association invariably has its nexus in the ability of host-country, home-country and third-country lawyers to associate within the establishment. More precisely, are they entitled (1) to become partners in or employees of non-hostcountry lawyers and firms having establishments in the host country, and (2) as members of the legal staff of such an establishment, freely to provide legal services in their capacity as host-country legal professionals?

Other issues of potential importance are the right of the establishment to practice under its home-country name, the legal form that the establishment may take, and the right of home-country lawyers to use their home-country titles. These issues seem to create obstacles, however, only in countries that are restrictive in regard to scope of practice and right of association. In other words, such questions as those of firm name, legal form, and the title to be used by home-country lawyers seem to be troublesome only in jurisdictions that are otherwise restrictive in regulating the right of establishment, and may be little more than somewhat gratuitous topics seized upon in those jurisdictions in order further to qualify the right of establishment.

It might be added that, universally, host-country establishments are subjected to the professional disciplinary rules applicable to domestic lawyers and firms in the host country. In a sense, this regulatory feature serves to ratify the host country's commitment to rights of establishment for lawyers and firms from other countries, because it places them on a professional footing identical to that of domestic lawyers and firms in the host country. Only where the rules are significantly harsher for establishments of foreign firms than for the domestic profession do they put in question the host country's genuine commitment to rights of establishment.

Jurisdictions aspiring to the status of major centres of international practice are likely to adopt rules favourable to non-host-country firms with host-country establishments seeking to render legal services involving host-country law. It will follow that rules on scope of practice and on rights of association will be shaped in a manner permitting these establishments to supply such services. It will also follow that rules on other topics will avoid gratuitous restrictions of a formal or procedural nature.

In contrast, jurisdictions prey to local protectionist interests are likely to shape their rules so as to inhibit competition by establishments of lawyers and law firms having home countries other than the host country. The protectionist phenomenon may take many forms, but the protectionist motive is not hard to identify, and where it prevails in multilateral trade negotiations such as the Doha Round, the invariable 
upshot is a refusal to make specific commitments on legal services that are favourable to establishments entitled to render legal services involving host-country law. The picture is essentially that simple, and it seems unlikely to become more limpid when viewed through a patina of decontextualized terminology.

\section{GATS Alternatives to Specific Commitments on Legal Services}

Ordinarily, WTO Members negotiating with regard to services under the GATS also negotiate with regard to non-GATS items (industrial goods, agricultural products, intellectual property, trade policies) included in (to take the current example) the Doha Round. Trade-offs between Members with regard to unrelated items may therefore occur. Accordingly, the importance assumed by legal services may be measured by its utility as a trade-off in other areas (which need not necessarily involve services at all). Thus measured, legal services may be of relatively minor importance in the Doha Round. As a result, there quite possibly will be several WTO Members that make no specific commitments in respect of legal services, or whose specific commitments on legal services represent less than vigorous efforts to facilitate host-member rights of establishment for lawyers and law firms from other WTO home members. Such, at any rate, was the experience in the Uruguay Round.

Under the GATS, there are potential alternatives to the scheduling of specific commitments on legal services by WTO Members. One alternative is to treat the legal profession as a "discipline" in respect of which Members who are so inclined will mutually agree on specified professional rules and standards. As long as a mutualrecognition agreement is open to all Members willing to adhere to it, it has legitimacy under the GATS. ${ }^{27}$ Not inconceivably, the Doha Round will be the occasion for developing such a mutual-recognition agreement on legal services. Experience to date is not extremely encouraging, however, and suggests either that efforts to reach such an agreement will be less vigorous than negotiations for full-blown specific commitments by WTO Members; or that, if they produce such an agreement, it will be one phrased in terms of generalities that put to one side the hard regulatory questions affecting cross-border legal practice. ${ }^{28}$

One requirement under the GATS is that every WTO Member must make it possible for legal professionals from other WTO Members to requalify as legal professionals in the Member State in question. ${ }^{29}$ Thus, in a given WTO Member, there must exist procedures whereby legal professionals from all other WTO Members can become candidates entitled to qualify for the legal profession of the WTO Member in question. This is a rather minimalist requirement, forbidding a restriction based solely on nationality. Hence, it is legitimate for requalification to

27 GATS Article VII.

28 See International Bar Association, GATS: General Agreement on Trade in Services, a handbook (London: International Bar Association, May 2002), at p. 35.

${ }^{29}$ GATS Article VI(6). 
subject candidates from other WTO Members, even when they are already qualified legal professionals, to the same requirements imposed on nationals of the WTO Member in question who are not qualified legal professionals. These requalification requirements may involve educational prerequisites, examinations, and linguistic facility that, singly or cumulatively, are not easily coped with by candidates from other countries, and that may prove irksome for those legal professionals who have years of experience as duly licensed legal practitioners.

It is possible that the subject of requalification by legal professionals will be discussed in the Doha Round, and that an effort will be made to remove some of the more irksome strictures imposed in various WTO Members. As a general matter, those WTO Members that tend to favour a meaningful right of establishment for lawyers and law firms from other countries also tend to make requalification relatively accessible. Where the right of establishment is the subject of favourable rules, requalification is likely, also, to be the subject of favourable rules. ${ }^{30}$ As a consequence, multilateral negotiations on requalification may not prove to be a useful substitute for negotiations on the right of establishment. Indeed, the opposite may be true, and it may turn out that progress in the area of requalification will follow once significant results have been obtained in multilateral negotiations on the right of establishment.

\section{CONCLUSION}

Through a process of elimination and after the various arguments have been weighed, a tentative conclusion, which may provide the basis for a more definitive conclusion as the Doha Round unfolds, can be reached at this stage, to the effect that legal services have been properly included in the Doha Round. The weighing of arguments will be found below. The process of elimination takes account of the four topics discussed above, and does so in the following manner.

- When compared with other WTO Members, the European Union and the United States are in a class by themselves, both as host-member users of legal services supplied by establishments of law firms from other WTO Members, and as the creators of legal-service establishments in other host members. Much of their predominance as both users and creators of such establishments rests on the many EU legal-service establishments in the United States, and the many US legal-service establishments in the European Union. It might therefore be tempting for the European Union and the United States to exploit their predominance by undertaking bilateral negotiations instead of participating in the multilateral Doha Round. Such a bilateral approach does not appear particularly promising, however, upon examination of (a) the

30 E.g., Qualified Lawyers Transfer Regulations 1990 governing the qualification of foreign lawyers as English solicitors; $\$ 520.6$ of the Rules of the New York Court of Appeals, enabling foreign-educated lawyers to take the New York State Bar Examination. 
disparate regulatory systems for legal services in each of the European Union and the United States, (b) the somewhat limited bilateral concessions that each of them might reasonably expect from the other, and (c) the concessions involving rights of establishment that each of them may be seeking in, for example, Asia and Latin America. With regard to the last point, there is the further consideration that, under the GATS, bilateral concessions would have to be extended to other WTO Members (such as those in Asia and Latin America) on an MFN basis, unless WTO Members agreed to exempt the EUUS bilateral concessions from MFN treatment. These considerations strongly suggest that, although the European Union and the United States are unquestionably predominant with regard to legal services, their interests would be better served by the Doha Round than by any bilateral arrangement within the realm of feasibility.

- It can be expected that the predominance of the European Union and the United States in the area of legal services will provoke a negative reaction in the Doha Round from WTO Members that question the consequences of globalization for countries that are relatively non-industrialized. Whatever the logic underlying this anti-globalization factor, particularly with regard to legal services, it may represent a constant to be reckoned with in the Doha Round. One way to reckon with it, of course, would be to exclude legal services from the Doha Round. The basic thrust of arguments against globalization have relatively little to do with legal services, however, as compared with other topics of far greater economic importance being negotiated in the Doha Round, and it therefore would seem altogether out of proportion to single out legal services for exclusion. Inasmuch as issues relating to globalization transcend the questions that will require resolution in the legal-service negotiations, it would seem that those issues can be reasonably put to one side in the strict context of the legal-service negotiations.

- Efforts to adopt an abstract of decontextualized terminology through which the legal-services negotiations will find expression seem unlikely to advance the objective of promoting cross-border rights of establishment for law firms in WTO home-member countries. The essence of a right of establishment must originate not from above through a GATS-wide terminological superstructure, but from below, jurisdiction-by-jurisdiction, through local decisions grounded in local experience and jurisprudence. Similarly, protectionist policies inimical to such a right of establishment are of parochial origin, and the proposed terminology can equally well be used by local interests to mask protectionist objectives. This being said, it seems unlikely that an otherwise propitious round of multilateral negotiations on legal services will founder by virtue of a proposed terminological superstructure. The lesson to be learned, it would seem, is not that the round should be abandoned, but 
that, in pursuing it, the participants should remain especially aware of the parochial underpinnings of the topic being dealt with.

- In the area of legal services, the GATS provides for possible alternatives to a round of negotiations ending with schedules of specific commitments. Those WTO Members that are so inclined might instead attempt to produce a mutual-recognition agreement, or a similar understanding, setting out certain rules and standards relating to the practice of law. Past experience seems to suggest, however, that this type of approach tends to produce rather vague generalities which, when all is said and done, do not compare favourably with multilateral negotiations for schedules of specific commitments. Although the latter may be spotty, yielding only a patchwork of rights of establishment, these rights, once in place, are reinforced by the contractual framework of the GATS, and by the institutional and dispute-resolution resources of the WTO.

The principal argument against including legal services in the Doha Round is that they are fundamentally parochial, deeply rooted in variegated systems of legal education, legal values, juridical oversight, professional rules, and cultural attitudes; and that the GATS is ill-suited to dealing with this heterodoxy of jurisprudential parochialisms. The principal argument for including legal services in the Doha Round is that, notwithstanding the argument summarized in the preceding sentence, legal services were included in the Uruguay Round and were there the subject of several specific commitments. Admittedly, those commitments, taken together and viewed in the context of the many WTO Members that did little or nothing in the way of making legal-service commitments, were rather limited. The Uruguay Round nonetheless represented a tangible beginning in the area of legal services; and a failure to follow up in the Doha Round could rightly be viewed as a step backward, as abandoning cross-border rights of establishment to the risks and vagaries of out-andout protectionism.

In the end, protectionism - the threat of protectionist barriers to cross-border rights of establishment-seems to hold the key to the question of whether legal services should be included in or excluded from the Doha Round. The argument for exclusion is that the GATS, while an agreement aimed at eliminating protectionist barriers, is not well suited to the parochial problems and features encountered when dealing with rules on the supply of legal services. In brief, it can be argued that legal services fit but awkwardly in the GATS, and the GATS must be tortured more than a little to fit around legal services.

Once this poor fit has been recognized, explicated and regretted, the fact remains that protectionism is the enemy of cross-border rights of establishment. This being true, it would seem altogether desirable also to recognize that the GATS as a WTO core agreement represents a vital multilateral force designed to roll back protectionism. It would be a bit much to expect the WTO and the GATS to be perfectly designed for every individual category of business and professional services, much less for so eclectic 
a sub-subcategory as legal services. Despite the imperfections that must be dealt with when legal services are fitted into the Doha Round, that is, into the current round of WTO negotiations, and into the applicable WTO agreement, that is, the GATS, proponents of cross-border rights of establishment would seem well advised to think themselves fortunate that the WTO and the GATS exist, and, accordingly, to try to make the most of the opportunities inherent in the Doha Round. 